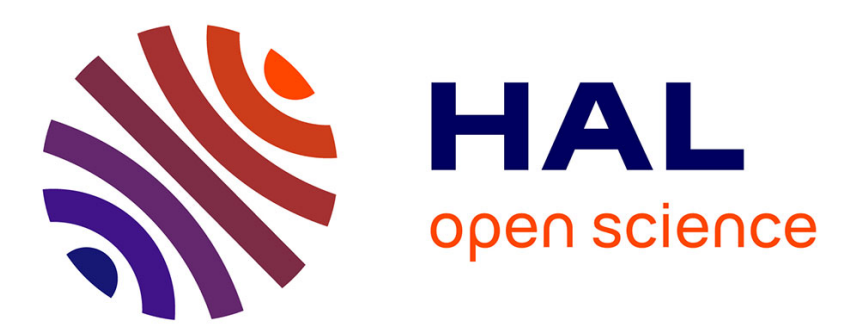

\title{
Axial behaviour of jacket piles for offshore wind turbines
}

Rocio Isorna, Matthieu Blanc, Luc Thorel, Panagiotis Kotronis, Christophe

Dano, Maxime Philippe

\section{To cite this version:}

Rocio Isorna, Matthieu Blanc, Luc Thorel, Panagiotis Kotronis, Christophe Dano, et al.. Axial behaviour of jacket piles for offshore wind turbines. International Journal of Physical Modelling in Geotechnics, 2017, 17 (4), pp.229-245. 10.1680/jphmg.15.00044 . hal-02014590

\section{HAL Id: hal-02014590 \\ https://hal.univ-grenoble-alpes.fr/hal-02014590}

Submitted on 13 Feb 2019

HAL is a multi-disciplinary open access archive for the deposit and dissemination of scientific research documents, whether they are published or not. The documents may come from teaching and research institutions in France or abroad, or from public or private research centers.
L'archive ouverte pluridisciplinaire HAL, est destinée au dépôt et à la diffusion de documents scientifiques de niveau recherche, publiés ou non, émanant des établissements d'enseignement et de recherche français ou étrangers, des laboratoires publics ou privés. 


\section{Axial behaviour of jacket piles for offshore wind turbines}

Rocio Isorna Eng, MSc

PhD Student, Ecole Centrale de Nantes, Université de Nantes, CNRS, Institut de Recherche en Génie Civil et Mécanique (GeM) and INNOSEA Nantes, France (corresponding author: rocio.isorna@ec-nantes.fr)

Matthieu Blanc Eng, MSc, PhD

Research Engineer, LUNAM Université, IFSTTAR, Department GERS,

Laboratory Geomaterials and Modeling in Geotechnics, Bouguenais Cedex, France

Luc Thorel Eng, MSc, PhD, HDR

Research Director, IFSTTAR, Department GERS, Laboratory Geomaterials and Modeling in Geotechnics, Bouguenais Cedex, France
Panagiotis Kotronis Eng, MSc, PhD, HDR

Professor, Ecole Centrale de Nantes, Université de Nantes, CNRS, Institut de Recherche en Génie Civil et Mécanique (GeM), Nantes, France

Christophe Dano Eng, MSc, PhD

Associate Professor, Grenoble Alpes University, 3SR Laboratory, Grenoble, France; formerly Institut de Recherche en Génie Civil et Mécanique (GeM), Ecole Centrale Nantes, Nantes, France

Maxime Philippe Eng, MSc, PhD

Research Director, INNOSEA, Nantes, France

To improve our understanding and to quantify the behaviour of a jacket foundation for offshore wind turbines, several tests have been conducted using a geotechnical centrifuge at $\mathbf{1 0 0} \mathrm{g}$. The monotonic tension and compression tests carried out on single small-scale model piles (prototype dimensions: $\mathbf{1 . 8} \mathbf{m}$ in diameter and an embedment depth of $40 \mathrm{~m}$ in dense sand) jacked at $1 \mathrm{~g}$ and $100 \mathrm{~g}$ show the influence of the set-up method on the axial ultimate capacity and on the tip and shaft resistances. The pile axial capacity in compression is improved, whereas the normalised displacement of the pile is bigger in tension when piles are jacked at $1 \mathrm{~g}$. Vertical cyclic loads on single piles jacked at $1 \mathrm{~g}$ (pure tension tests or two-way tests) and horizontal cyclic loads on a four-pile jacket structure are applied to examine the behaviour under more realistic loading paths. The piles of the jacket structure are considered and studied as singles piles. Finally, the stability diagrams for the single and the jacket piles are discussed to visualise the significant difference in performance of a single pile against the comparable pile in the jacket.

$\begin{array}{ll}\text { Notation } \\ a & \text { coefficient } \\ B & \text { pile diameter } \\ b_{\mathrm{cpt}} & \text { cone diameter } \\ C_{\mathrm{u}} & \text { soil uniformity coefficient } \\ c_{\mathrm{v}} & \text { coefficient of consolidation } \\ G_{\mathrm{s}} & \text { soil shear modulus } \\ \boldsymbol{g} & \text { earth gravity } \\ H & \text { horizontal or lateral load } \\ H_{\mathrm{a}} & \text { average horizontal load } \\ H_{\mathrm{cy}} & \text { horizontal cyclic load amplitude } \\ H_{\mathrm{max}} & \text { horizontal maximum load } H_{\mathrm{max}}=H_{\mathrm{a}}+H_{\mathrm{cy}} \\ H_{\mathrm{min}} & \text { horizontal minimum load } H_{\mathrm{min}}=H_{\mathrm{a}}-H_{\mathrm{cy}} \\ h & \text { horizontal displacement } \\ h^{\prime} & \text { vertical distance from the tip } \\ k & \text { soil permeability } \\ L & \text { pile length } \\ N & \text { number of cycles } \\ N_{\mathrm{f}} & \text { number of cycles at failure } \\ P_{\mathrm{a}} & \text { atmospheric pressure } \\ P n & n \text {th pile of the jacket } \\ q_{\mathrm{c}} & \text { cone penetration resistance } \\ s & \text { settlement } \\ s_{\mathrm{u}} & \text { ultimate settlement } \\ & \end{array}$

\begin{tabular}{|c|c|}
\hline$V$ & vertical load \\
\hline$V_{\mathrm{a}}$ & average load \\
\hline$V_{\text {cy }}$ & cyclic load amplitude \\
\hline$V_{\mathrm{d}}$ & adimensional parameter \\
\hline$V_{\max }$ & maximum load $V_{\text {max }}=V_{\mathrm{a}}+V_{\mathrm{cy}}$ \\
\hline$V_{\min }$ & minimum load $V_{\min }=V_{\mathrm{a}}-V_{\mathrm{cy}}$ \\
\hline$V_{\mathrm{u}, \mathrm{c}}$ & $\begin{array}{l}\text { ultimate compression capacity (bearing capacity } \\
\text { in compression) }\end{array}$ \\
\hline$V_{\mathrm{u}, \mathrm{t}}$ & $\begin{array}{l}\text { ultimate tension capacity (bearing capacity } \\
\text { in tension) }\end{array}$ \\
\hline$v_{\mathrm{r}}$ & displacement rate \\
\hline$z$ & depth \\
\hline$\Delta r$ & mean radius of soil particles \\
\hline$\Delta \sigma_{\mathrm{rd}}^{\prime}$ & radial effective stress variation due to axial loading \\
\hline$\delta$ & friction angle of the soil-pile interface \\
\hline$\sigma$ & axial stress \\
\hline$\sigma_{\mathrm{rf}}^{\prime}$ & radial effective stress at failure \\
\hline$\sigma_{\mathrm{vo}}^{\prime}$ & free-field effective vertical stress \\
\hline & shear stress at failure \\
\hline
\end{tabular}

\section{Introduction}

Varying foundation types (gravity structures, monopiles, suction buckets, piled jackets, etc.) are used by the offshore 
wind industry. The choice depends mainly on site geotechnical conditions, load intensities and water levels. The primary role of these foundations is to transfer safely lateral and axial loads (monotonic, cyclic or dynamic) into the ground.

For moderate water levels (depths within the range 20-50 m), jacket steel structures are commonly used. A typical jacket structure is made of a steel space frame connected to three or four piles. This supporting structure is used to transfer the complex combination of axial and lateral loads from the wind turbine tower to the four piles with a main axial component. This paper addresses the problem of the response of single piles and jacket foundations under axial loading and presents the results of geotechnical centrifuge experiments conducted to examine the significant difference between single pile and jacket pile performances.

The common practice in pile design is based on the disconnection of axial and lateral components. Regarding the axial behaviour, cone penetration test (CPT) based methods are often used (Clausen et al., 2005; Jardine et al., 2005; Kolk et al., 2005; Lehane et al., 2005). A detailed literature review is presented in Schneider et al. (2008). As for the lateral components, American Petroleum Institute (API, 2011) or Det Norske Veritas (DNV, 1977, 2012) design rules propose a reduction of the $p-y$ curves in order to take into account the potential degradation of the pile capacity due to lateral cyclic loads (Cuellar, 2010). Yet, no recommendations are provided as regards axial cyclic loads, although they can under certain conditions significantly reduce the pile axial capacity and cause premature failure. Eurocode 7 (NF P 94-262 (Afnor, 2012)) identifies the potential vulnerability of piles subjected to cyclic loading without, however, providing any detailed recommendation.

The influence of axial cyclic loading on pile foundations in sandy soils has been investigated through studies using either laboratory models (Chan and Hanna, 1980; Rimoy et al., 2012; Tsuha et al., 2012), centrifuge models (Guefrech et al., 2012; Khemakhem et al., 2012; Rosquöet et al., 2013) or field observations (ACL, 2000; Andersen et al., 2013; Benzaria et al., 2013; Chow, 1997; Jardine and Standing, 2000, 2012; Lehane, 1992; Puech, 2013; Puech and Jézéquel, 1980). Poulos (1988) introduces the concept of 'stability diagrams' for piles, in which stability, instability or metastable stability zones are defined depending on the average $V_{\mathrm{a}}$ and $V_{\mathrm{c}}$ cyclic axial loads. The main conclusion is that, in loose sands, the metastable zone is larger than the stable zone (the ratio $V_{\mathrm{c}} / V_{\mathrm{uc}}$ below which the behaviour can be considered as stable is lower than $0 \cdot 2$, where $V_{\mathrm{c}}$ is the half-amplitude of the cyclic component of the axial load and $V_{\text {uc }}$ is the compression capacity of the pile). In loose sands, the stable zone is limited due to the contractive volumetric behaviour at the soil/pile interface, which produces a decrease in effective radial stress that results in shaft friction losses. It is worth noting, however, that the previous results on axial capacity involve mainly single piles.

The purpose of this study is to examine the significant performance difference between a single pile against the comparable pile in a jacket foundation and the influence of the installation conditions. With this aim in view, the experimental study presented focuses on the behaviour of single offshore large piles and of a jacket foundation during centrifuge tests conducted in sandy soil. The experimental programme consists in the following.

- A first series of tests carried out on single piles, hydraulically jacked into the sand at $1 \mathrm{~g}$ or $100 \mathrm{~g}$. The impact of the installation procedure on pile axial capacity is studied. Then the piles are monotonically axially loaded.

- Some piles jacked at $1 \boldsymbol{g}$ are also tested under cyclic axial loading in order to build the stability diagram.

Finally, a four-pile jacket structure is tested under horizontal cyclic loading at $100 \mathrm{~g}$.

\section{Physical modelling}

\subsection{Soil sample}

The NE34 Fontainebleau sand currently used for French institute of science and technology for transport, spatial planning, development and networks (IFSTTAR) centrifuge modelling is a siliceous fine sand of marine origin made of subangular particles. Its minimum and maximum dry unit mass stand within the range $1.417-1.736 \mathrm{~g} / \mathrm{cm}^{3}$. The mean grain size, $d_{50}$, is $\sim 0 \cdot 2 \mathrm{~mm}$ and the uniformity coefficient is $C_{\mathrm{U}}=d 60 / d 10=1 \cdot 6$.

The dry Fontainebleau sand used in all the tests presented here has been deposited at a $1 \boldsymbol{g}$ level using the air pluviation technique (Garnier et al., 1993) in a rectangular steel container (a strongbox), whose inner dimensions are $1.20 \mathrm{~m}$ long by $0.8 \mathrm{~m}$ wide and $0.72 \mathrm{~m}$ deep. The sand relative density is controlled by adjusting the falling height between the hopper and the surface of sand $(900 \mathrm{~mm})$, the opening $(3 \mathrm{~mm})$ and the hopper horizontal speed ( $3 \mathrm{~mm}$ and $18.2 \mathrm{~cm} / \mathrm{s}$, respectively) in order to obtain dense sand (relative density of $97 \%$ ). The unit mass is measured in three containers (C4, C5 and C6) using calibrated boxes placed at the bottom of the container before pluviation starts. The average unit mass obtained is $1.69 \mathrm{~g} / \mathrm{cm}^{3}$ with an error of $0.03 \%$. Seven containers are prepared and tested. In container C5, two CPT tests are carried out to assess the quality of the soil mass and provide information for the subsequent analysis (Table 1).

Piles or jackets are then installed (partially or fully as described later) using a hydraulic jack at $1 \boldsymbol{g}$. In this study, only 
Container Number of tested piles Number of tested jackets

\begin{tabular}{lcc}
\hline C1 & 5 & - \\
C3 & 1 & - \\
C4 & - & 1 \\
C5 & - & 1 \\
C6 & 3 & - \\
C7 & 3 & -
\end{tabular}

Table 1. Details of tests per container

the quasi-static loads applied to the piles are considered. The soil behaviour is assumed to be drained.

To prevent boundary effects, the minimum distance between the container wall and the piles is equal to ten times the pile diameter $B$ and the distance between the pile tip and the bottom of the container is more than 17 times the pile diameter $B$.

\subsection{Single pile model}

The model pile, scaled at $1 / 100$, is an aluminium cylinder with an outer diameter of $18 \mathrm{~mm}$, a wall thickness of $0.65 \mathrm{~mm}$ and a total length of $450 \mathrm{~mm}$ (Figure 1(a)). The roughness of the pile surface is mechanically machined to obtain a normalised roughness equal to 1 (Lings and Dietz, 2005).

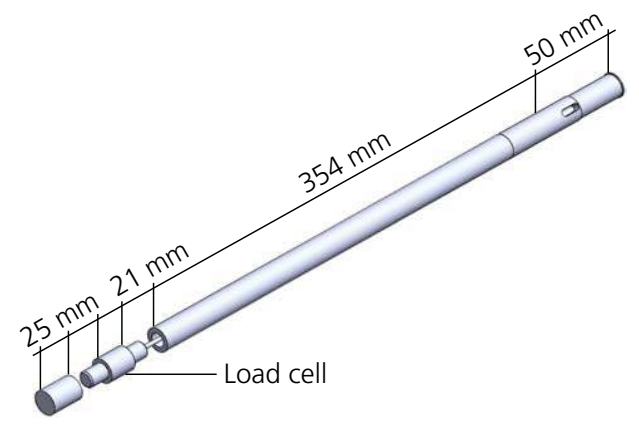

(a)

Figure 1. (a) Model pile and (b) centrifuge experimental set-up for a single pile
During the tests, the piles are driven into the soil sample over a length of $400 \mathrm{~mm}$. The pile tip is flat and close-ended (although offshore foundations are usually open-ended, in centrifuge tests, an open-ended pile can generate some arching effects and create a gap inside the pile during the installation procedure). The pile is instrumented with a Measurement Specialties XF3057 sensor having a maximal tension and compression capacity of $25 \mathrm{kN}$. The sensor is $21 \mathrm{~mm}$ high and placed at $25 \mathrm{~mm}$ from the pile tip. The head of the pile is composed of a hollow cylinder with a total length of $404 \mathrm{~mm}$ and an inner diameter of $5 \mathrm{~mm}$ to allow the power and measuring cable of the sensor through.

\subsection{Single pile set-up}

A hydraulic jack controlled by a loop-back controlled loading system (MOOG ST003014-205) positioned on the centrifuge axis is used to apply axial monotonic and cyclic loads on the pile.

The hydraulic jack, supporting a load cell with a capacity of $25 \mathrm{kN}$, is positioned axially (vertically) above the pile (Figure 1(b)). Below the load cell, a ball joint ensures a nil moment during the connection between the pile head and the driving loading system. The load cell is used to measure the weight increase during the $\boldsymbol{g}$ level increase and the pile bearing capacity. The combination of the two load cells, in the head and at the tip of the pile, makes it possible to break down the bearing capacity into the shaft and the tip resistance of the pile.

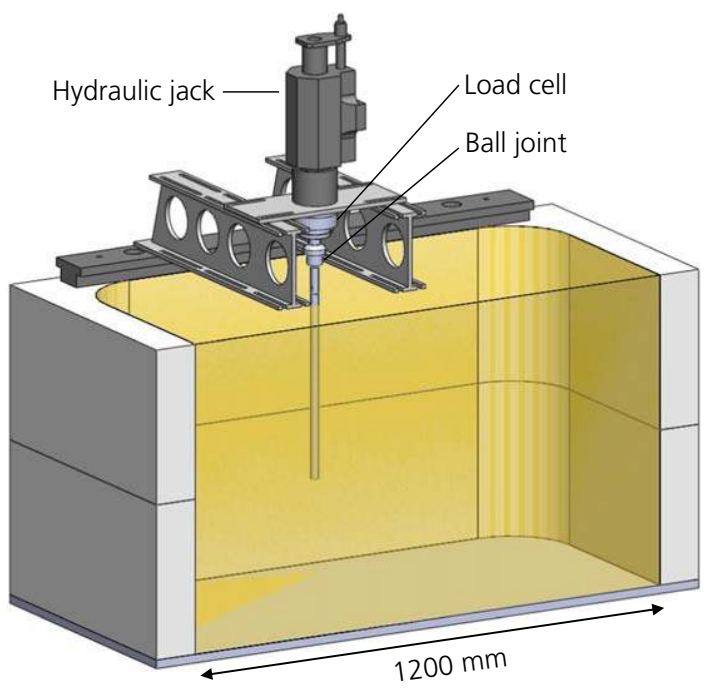

(b) 
A flat horizontal rectangular piece of aluminium is fixed on the ball joint to define the reference point of axial displacement. A magnetostrictive displacement sensor (MAGNOSENS

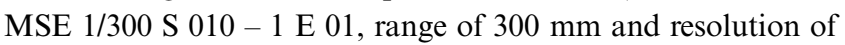
$10 \mu \mathrm{m})$ is placed at the end of the hydraulic jack to measure or control axial displacements.

\subsection{Jacket structure model}

A four-legged jacket structure ( $\mathrm{P} 1-\mathrm{P} 4$ piles) is tested at a maximum centrifugal acceleration of $100 \mathrm{~g}$. The four model piles used for the jacket structure are similar to the single pile described above. The pile heads are connected using a square aluminium platform (250 mm of sides) (Figure 2). A $620 \mathrm{~mm}$ high aluminium frame represents the jacket space frame. The jacket substructure is represented by the frame and the platform. The horizontal loads applied on the top of the jacket space frame $(670 \mathrm{~mm}$ above the ground level) are transferred to the platform as couples of forces, bending moments and torsion, resulting in axial loads within the four piles.

Two configurations are tested: $(a) 0^{\circ}$ position as displayed in Figure 2, where the horizontal loads are transferred to the four piles and (b) $45^{\circ}$ position, where the frame is positioned on the platform diagonally. In this configuration, the horizontal loads are transferred to the two piles on the diagonal. To prevent boundary effects, for both configurations the distance from the piles to the container wall is ten times the pile diameter. The weight of the substructure for the $0^{\circ}$ and $45^{\circ}$ positions is $2 \cdot 12$ and $2.18 \mathrm{~kg}$, respectively (an extra piece is needed for the $45^{\circ}$ configuration).

\subsection{Jacket set-up}

A horizontal hydraulic jack is used to apply lateral loading to the jacket structure (Figure 2). The load cell has a maximal capacity of $5 \mathrm{kN}$. The magnetostrictive displacement sensor described in Section 2.3 is placed at the extremity of the hydraulic jack to measure the jacket head displacement.

Each of the four foundation piles is instrumented with a load cell placed $46 \mathrm{~mm}$ from the tip (as the single pile, §2.2). Since there is no sensor to measure the load at the top of each pile, a numerical three-dimensional (3D) model of the foundation has been developed using SolidWorks and the Abacus finiteelement solver. In the numerical model, the behaviour of the jacket foundation is considered linear elastic. Two boundary conditions were adopted for the piles: clamped or linked with axial and lateral springs (reproducing approximately the nonlinear behaviour of soil). The axial spring was calibrated from the monotonic tests and the lateral springs using $p-y$ curves from the literature (API, 2011). Results were similar for both models. The combination of experimental and numerical data

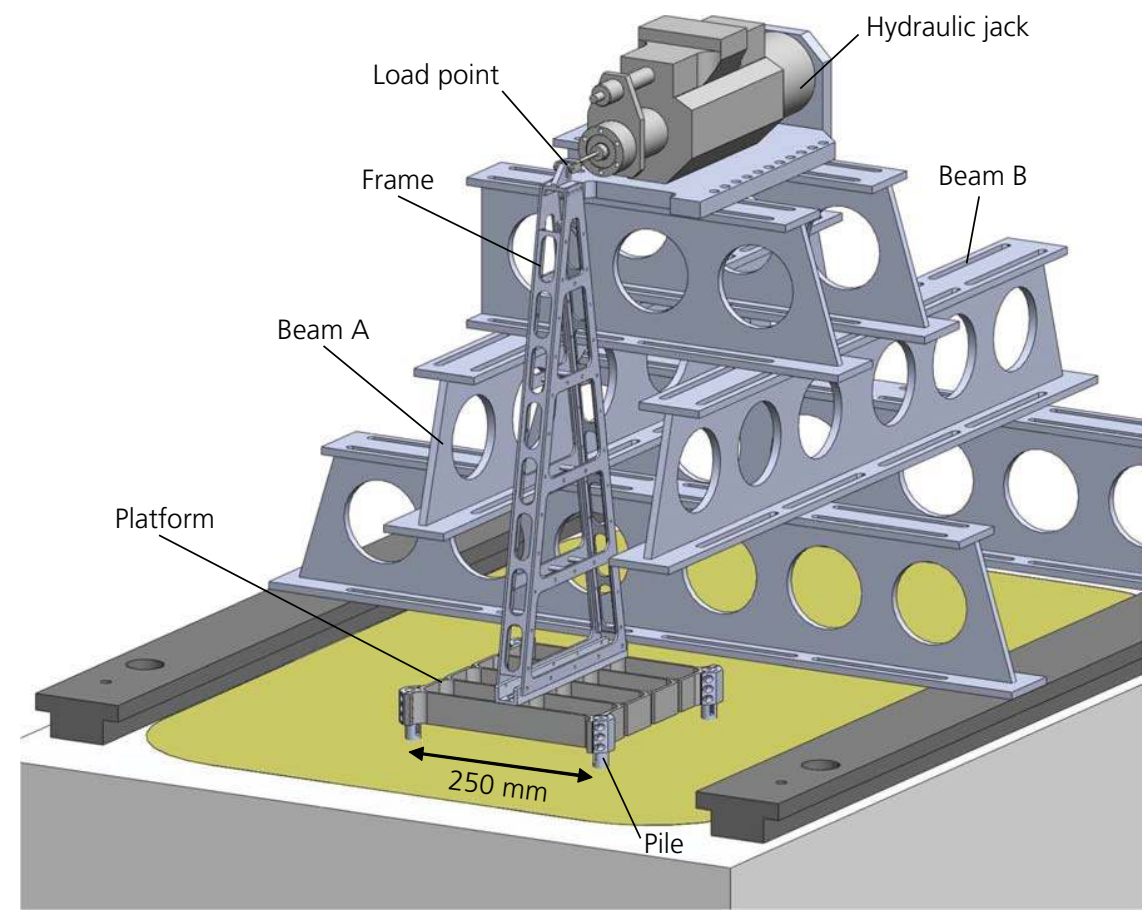

Figure 2. Centrifuge experimental set-up ( $0^{\circ}$ jacket test) 
allowed for the quantification of load distribution within the piles.

Four laser displacement transducers (similar to those described in Section 2.3) are used, two on beam A and two on beam B (Figure 2). Each laser pointing to a pile head can measure its axial displacement.

\section{Experimental campaigns}

The model piles are jacked in-flight into the sand at $1 \boldsymbol{g}$, with a few exceptions, for which the pile installation is partially performed at $100 \mathrm{~g}$ to study the influence of the installation procedure on the pile behaviour.

In this study, quasi-static loads are applied and the soil behaviour is assumed to be drained. It is commonly accepted that drained monotonic penetration occurs when the soil permeability coefficient $k$ is larger than $10 \times 10^{-6}$ to $10 \times 10^{-5} \mathrm{~m} / \mathrm{s}$ (McNeilan and Bugno, 1985), which is the case for uniform NE34 Fontainebleau sand. The behaviour of a saturated soil on cyclic loading depends on the soil permeability $k$ or the coefficient of consolidation $c_{\mathrm{v}}$, the dimensions of the penetrating object (in the authors' case the pile diameter) and the load or displacement rate. Previous studies have shown that this behaviour could be characterised as fully drained (high $k$, low rates), as fully undrained (low $k$, high rates) or as partially drained (intermediate conditions). The boundaries between these different drainage conditions have been determined experimentally using cone penetrometer or T-bar tests (Finnie and Randolph, 1994; Lehane et al., 2009) or using pressuremeter tests (Rangeard et al., 2002). Due to the obvious similarities with piles, the cone penetrometer results are considered hereafter. Transition is defined through an adimensional parameter $V_{\mathrm{d}}=v_{\mathrm{r}} b_{\mathrm{cpt}} / c_{\mathrm{v}}$, where $v_{\mathrm{r}}$ is the displacement rate (or cone velocity), $b_{\mathrm{cpt}}$ is the cone diameter and $c_{\mathrm{v}}$ is the coefficient of consolidation. Fully drained conditions are obtained in centrifuge for $V_{\mathrm{d}}<0 \cdot 01$ (mainly for silty sands) and fully undrained conditions for $V_{\mathrm{d}}>30$. The difficulty arises here in the estimation of the $c_{\mathrm{v}}$ coefficient for sand. Nevertheless, even if a conservative value of $c_{\mathrm{v}}$ equal to $10 \times 10^{-6} \mathrm{~m}^{2} / \mathrm{s}$ and the worst loading conditions (cyclic tests) are assumed, this leads to $V_{\mathrm{d}}$ of about $0 \cdot 6$. Fully undrained conditions are therefore not fulfilled.

In reality, the prototype pile is placed in wet sand and therefore the Archimedes' principle is applied; the buoyancy load is equal to $1 \mathrm{MN}$ (volume $\times$ water density $=101 \mathrm{~m}^{3} \times 9 \cdot 8 \mathrm{kN} / \mathrm{m}^{3}$ ). This value is considered negligible; it represents 2 and $0.9 \%$ of the pile tension and compression capacity, respectively.

The use of dry sand in the experiment (model) results in effective stresses around the piles different from the prototype, which is placed in wet sand. This is because they are based on dry rather than buoyant unit weight. Therefore, a pile that is $400 \mathrm{~mm}$ long at $100 \mathrm{~g}$ in dry sand does not exactly represent a $40 \mathrm{~m}$ long pile in wet sand. To quantify the difference, the impact of unit weight on pile tension resistance is studied hereafter (the Imperial college pile (ICP)-05 method does not consider the unit weight for the bearing capacity (compression)).

Using the ICP-05 method (Jardine et al., 2005) and the prototype pile geometry (diameter $=1.8 \mathrm{~m}$ and length $=40 \mathrm{~m}$ ), the tension pile resistances for buoyancy and dry unit weight are calculated. In both cases, the same interface friction angle, $\delta$ and cone penetration resistance, $q_{\mathrm{c}}$ values were considered. Results have shown that the radial stresses around the pile are smaller for the wet soil than for the dry soil. There is a $7 \%$ difference in tension capacity.

\subsection{Monotonic axial loading of single piles}

\subsubsection{Test chronology}

The piles are first jacked at a constant speed of $0.1 \mathrm{~mm} / \mathrm{s}$ using a hydraulic jack at $1 \mathrm{~g}$. Then, the sensors are reset to zero, the data acquisition starts and the $\boldsymbol{g}$ level is increased up to $100 \mathrm{~g}$. During this phase, the soil and the pile settle in different proportions causing positive and negative frictions along the shaft. No load is applied on the pile head until the acceleration reaches $100 \mathrm{~g}$. The axial load is then applied on the pile head thanks to the hydraulic jack using a displacement (for monotonic axial tests) or a force (for cyclic axial tests) controlled mode.

Piles fully jacked at $1 \boldsymbol{g}$ are used for the modelling of bored or cast-in-place piles. Some piles are partially jacked at $1 \boldsymbol{g}$ while the installation is completed at $100 \mathrm{~g}$ (on 5 or $10 \mathrm{~m}$ ) until the intended embedded length is reached ( $40 \mathrm{~m}$ on the prototype scale). Due to centrifuge limitations, fully modelling the installation of in-situ piles is not possible. Then, the load is applied on the piles.

\subsubsection{Experimental programme}

A first series of six monotonic tests on single piles (Table 2) is carried out to examine the effect of the installation procedure as well as the loading direction (compression or tension) on axial capacity and load distribution, under monotonic loading.

For the three piles fully jacked at $1 \mathrm{~g}$, two of them are tested in compression ( $\mathrm{MC1}$ and $\mathrm{MC} 2$ ) and one in tension (ME1).

- Among the two piles partially jacked at $100 \mathrm{~g}$ over a $10 \mathrm{~m}$ length, one is tested in compression (DC1) and the other in tension (DE1).

- A pile is partially jacked at $100 \mathrm{~g}$ on $5 \mathrm{~m}$ and tested in compression (ref. DC2). 


\begin{tabular}{llcl} 
Test & Setting up & $\begin{array}{c}\text { Depth of } 100 \boldsymbol{g} \\
\text { jacking: } \mathrm{m}\end{array}$ & Load case \\
\hline MC1 & Jacked at $1 \boldsymbol{g}$ & - & Compression \\
MC2 & Jacked at $1 \boldsymbol{g}$ & - & Compression \\
ME1 & Jacked at $1 \boldsymbol{g}$ & - & Tension \\
DC1 & Jacked at $100 \boldsymbol{g}$ & $30-40$ & Compression \\
DC2 & Jacked at $100 \boldsymbol{g}$ & $35-40$ & Compression \\
DE1 & Jacked at $100 \boldsymbol{g}$ & $30-40$ & Tension
\end{tabular}

Table 2. Experimental programme for single piles under monotonic loading (prototype scale)

The test results are presented in terms of axial load $V$ against pile settlement (in compression) or heave (in tension) (Figure 3). These monotonic curves are useful to determine the axial compression capacity $V_{\mathrm{u}, \mathrm{c}}$ (using the double slope method (Blanc et al., 2015)) or the tension capacity $V_{\mathrm{u}, \mathrm{t}}$, from the maximum value. The settlement or heave corresponding to the capacity load is named hereafter $s_{\mathrm{u}, \mathrm{t}}$ (tension) and $s_{\mathrm{u}, \mathrm{c}}$ (compression).

\subsection{Cyclic axial loading on single piles}

Table 3 presents the cyclic loading programme applied on single piles. $V_{\text {a }}$ and $V_{\text {cy }}$ are the average load and the cyclic load half-amplitude of the applied sine signal, respectively. $V_{\max }$ and $V_{\min }$ are the maximum and minimum loads at the pile head during cyclic loading. Two types of tests are performed: one-way tensile tests, (COW1, COW2 and COW3) and two-way tests, alternating between compression and tension (CTW1, CTW2 and CTW3).

The CTW1 test corresponds to the case of a pile undergoing the load of a jacket offshore wind-turbine structure. The aerohydro-elastic load calculation of a jacket structure (with the same substructure height $(67 \mathrm{~m})$ and the distance between piles than the one used for the tests (the jacket substructure is considered to be anchored at mudline) is performed (INNOSEA, 2014). Environmental wind, waves and current loads are applied to the jacket model and its behaviour at mudline is calculated. The numerical maximal and minimal axial loads at mudline obtained are reproduced during the CTW1 test to study the pile behaviour under offshore load conditions. The load amplitudes for tests CTW2 and CTW3 are five and eight times higher than the CTW1 test conditions.

\subsection{Jacket structure tests under lateral loading}

\subsubsection{Test chronology}

The four piles are installed as isolated piles using a hydraulic jack at a constant speed at $1 \mathrm{~g}$. A trapezoidal piece with a larger bottom surface than the platform is connected to the hydraulic jack. This makes it possible to apply a uniform displacement over the platform to guarantee uniform jacking of the four piles.

After the pile installation, the frame structure is placed over the platform and connected to the hydraulic jack. Then, the $\boldsymbol{g}$ level is increased up to $100 \mathrm{~g}$. During this phase, the vertical

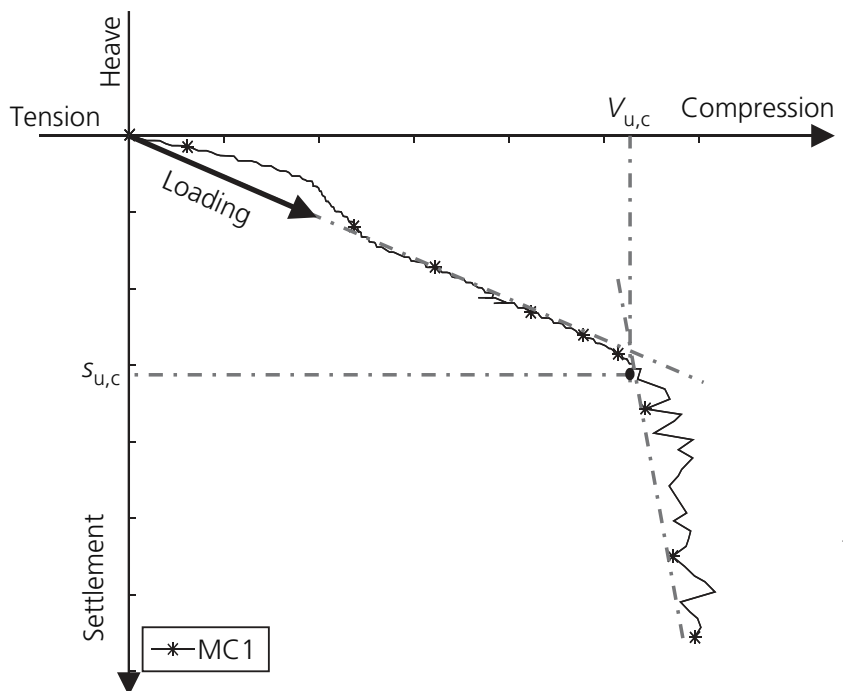

(a)

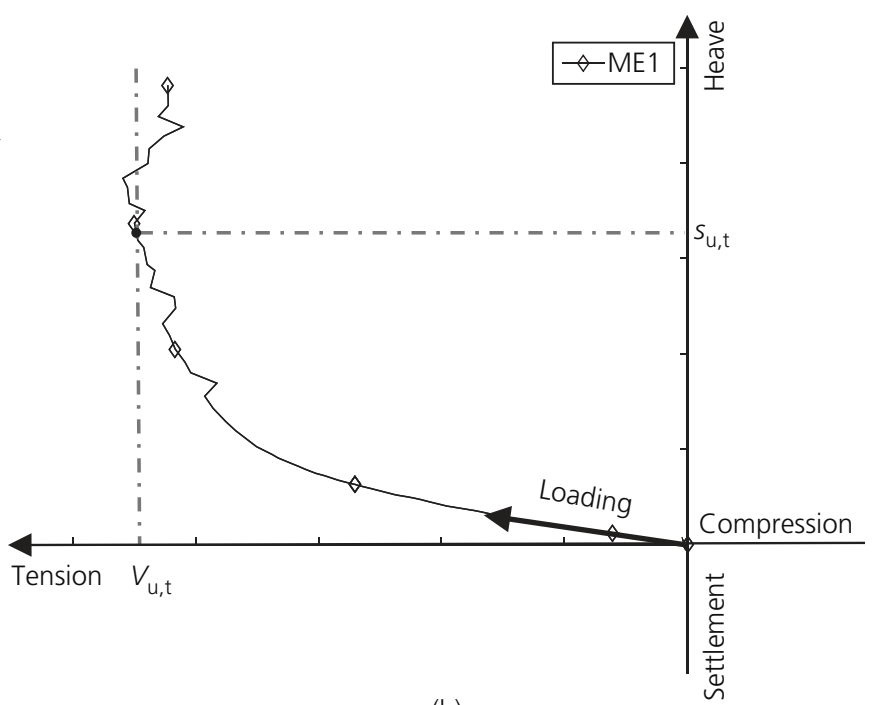

(b)

Figure 3. Monotonic axial loading test scheme: displacement against force for (a) tension and (b) compression 


\begin{tabular}{llcc} 
Test & Load case & $V_{\max } / V_{\mathrm{u}, \mathrm{c}}$ & $V_{\min } / V_{\mathrm{u}, \mathrm{t}}$ \\
\hline COW1 & One-way & 0 & 0.56 \\
COW2 & One-way & 0 & 0.84 \\
COW3 & One-way & 0 & 0.93 \\
CTW1 & Two-way & 0.06 & 0.45 \\
CTW2 & Two-way & 0.32 & 0.22 \\
CTW3 & Two-way & 0.51 & 0.36
\end{tabular}

Table 3. Experimental programme for single piles under cyclic loading (prototype scale)

load increases with the $\boldsymbol{g}$ level due to the dead load, but no horizontal load is applied. Once the $100 \mathrm{~g}$ acceleration is reached, the lateral load is applied in a force-controlled mode.

\subsubsection{Experimental programme}

Two cyclic tests with different configurations are conducted. Figures 4(a) and 4(b) represent tests JC00 and JC45, respectively, with $H$ being the horizontal applied force and P1, P2, P3

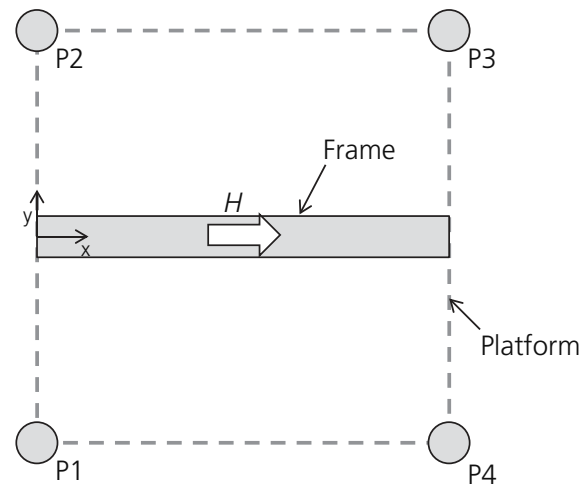

(a) and $\mathrm{P} 4$ being the four piles. $H_{\mathrm{a}}$ is the mean cyclic load and $H_{\text {cy }}$ its half-amplitude.

The different load cases are summarised in Table 4. Test JC45 is divided into two phases, JC45(a) and JC45(b), where JC45(b) mean and cyclic components of the cyclic load are twice the values of the JC45(a) test. Load cases for tests JC00 and $\mathrm{JC} 45(\mathrm{a})$ are equal to $H_{\min }$ of the CTW1 test (tension piles).

For each test, the piles are initially subjected to compression (due to the frame weight) before the horizontal load $H$ is applied (only one-way tests are performed). The relationship between the horizontal load $H$ and the vertical load $V$ is obtained through the numerical modelling of the jacket using a 3D model.

\section{Experimental results}

\subsection{Single piles under monotonic loading}

Monotonic tests are carried out to estimate pile axial capacity. Results are given in Table 5 and Figures 5 and 6. Figures 5(a)-5(d) present the data collected during pile installation at $100 \mathrm{~g}$ and

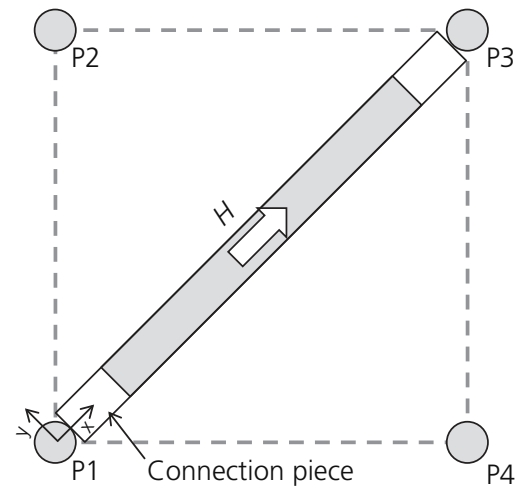

(b)

Figure 4. (a) Jacket test set-up for $0^{\circ}$ and (b) jacket test set-up for $45^{\circ}$

\begin{tabular}{|c|c|c|c|c|c|}
\hline Test & Load case & $H_{a} / V_{u, c}: \%$ & $H_{\mathrm{cy}} / V_{\mathrm{u}, \mathrm{c}}: \%$ & $H_{\max } / V_{\mathrm{u}, \mathrm{c}}: \%$ & $H_{\min } / V_{u, c}: \%$ \\
\hline $\mathrm{JCOO}$ & Cyclic & $2 \cdot 7$ & $2 \cdot 7$ & $5 \cdot 3$ & 0 \\
\hline$J C 45(a)$ & Cyclic & $2 \cdot 7$ & $2 \cdot 7$ & $5 \cdot 3$ & 0 \\
\hline$J C 45(b)$ & Cyclic & $5 \cdot 3$ & $5 \cdot 3$ & $10 \cdot 6$ & 0 \\
\hline
\end{tabular}

Table 4. Experimental programme for the jacket structure (prototype scale) 


\begin{tabular}{|c|c|c|c|c|c|}
\hline Test & $\begin{array}{l}\text { Embedment, } \\
\text { D: } \mathrm{m}\end{array}$ & $\begin{array}{c}\text { Capacity, } V_{u, c} \text { and } \\
V_{u, t}: M N\end{array}$ & $\begin{array}{l}\text { Ultimate displacement, } \\
\qquad s_{\mathrm{u}, \mathrm{c}} \text { and } s_{\mathrm{u}, \mathrm{t}}: \mathrm{m}\end{array}$ & $\begin{array}{l}\text { Ultimate normalised } \\
\text { displacement, } s_{\mathrm{u}} / B\end{array}$ & $\begin{array}{l}\text { Interface friction angle } \\
\text { from ICP: deg }\end{array}$ \\
\hline MC1 & 40 & 107 & 0.25 & 0.14 & $28 \cdot 7$ \\
\hline MC2 & 40 & 96 & 0.25 & $0 \cdot 15$ & $23 \cdot 5$ \\
\hline ME1 & 40 & -43 & $-0 \cdot 18$ & $-0 \cdot 1$ & $19 \cdot 9$ \\
\hline DC1 & 40 & 225 & 0.23 & $0 \cdot 12$ & $24 \cdot 7$ \\
\hline DC2 & 40 & 190 & 0.21 & 0.11 & $26 \cdot 8$ \\
\hline DE1 & 40 & -42 & -0.47 & -0.26 & $16 \cdot 2$ \\
\hline$D C 1 j$ & 30 & 69 & 0.14 & 0.08 & $21 \cdot 2$ \\
\hline$D C 2 j$ & 35 & 93 & 0.14 & 0.08 & $22 \cdot 3$ \\
\hline DE1j & 30 & 69 & 0.22 & 0.12 & $26 \cdot 3$ \\
\hline
\end{tabular}

$B$, pile diameter

Table 5. Monotonic loading test results (prototype scale)

Figures 6(a)-6(d) those collected during monotonic loading tests.

The pile head load against the displacement curves are plotted in Figures 5(a) and 6(a), where the $(0,0)$ point corresponds to the initial test state before loading (and after jacking at $100 \mathrm{~g}$ ). Figures 5(b) and 6(b) show the evolution of the load cell at the tip. The initial value of the sensor is due to the differential settlement between the soil and the pile during the $\boldsymbol{g}$ increase. In the upper part, the pile settlement is lower than that of the soil, thus creating positive friction. Below a certain depth, the opposite phenomenon takes place: the pile settlement is higher than the sand one, thus creating positive friction along the shaft and the increase of tip resistance.

For ME1 and DE1 piles (tension), the set-up method and the embedded length have no influence on pile tension capacity. However, piles jacked at $1 \mathrm{~g}$ save $61 \%$ of displacement to reach full shaft capacity in relation to piles jacked at $100 \mathrm{~g}$.

Compression $\mathrm{MC} 1$ and $\mathrm{MC} 2$ tests, where piles are jacked at $1 \mathrm{~g}$ in the same container and tested in the same conditions, reveal a difference of $10 \%$ in the pile capacity $V_{\mathrm{u}, \mathrm{c}}$ (MC2 $10 \%$ lower). The reason for this may be explained by a possible defect on pile verticality. However, this assumption could not be verified. The $V_{\mathrm{u}, \mathrm{c}}$ value used in the subsequent calculations is, therefore, considered as the average value of both tests - that is, $V_{\mathrm{u}, \mathrm{c}}=101 \cdot 5 \mathrm{MN}$.

The results obtained from the compression tests show that $V_{\mathrm{u}, \mathrm{c}}$ is higher for piles jacked at $100 \mathrm{~g}$ than for piles jacked at $1 \mathrm{~g}$ (DC1 and DC2). It also increases with the jacked length (the compression capacity increases by 87 and $121 \%$ from $5 \mathrm{~m}$ (DC2) to $10 \mathrm{~m}$ (DC1) jacked length, respectively). In spite of this significant difference in terms of capacity, the ultimate displacement for piles jacked at $100 \mathrm{~g}$ is only $26 \%$ greater than for piles jacked at $1 \boldsymbol{g}$.

In Figure 5(a), the jacking phase at $100 \mathrm{~g}$ (DC1, DE1, DC2) can be compared with the monotonic tests on piles previously jacked at $1 \boldsymbol{g}$ (results are presented in Table 5 as DC1j, DC2j and DE1j). Using the double slope method (Blanc et al., 2015), the axial capacity is $69 \mathrm{MN}$ for DC1 and DE1 and $93 \mathrm{MN}$ for DC2. These values are lower than in the MC1 and MC2 tests where piles are fully jacked at $1 \boldsymbol{g}$, which confirm the fact that the compression axial capacity increases with the embedded length.

The ratio of the tension to the compression capacities for tests performed with the same set-up method is calculated. The $V_{\mathrm{u}, t} / V_{\mathrm{u}, \mathrm{c}}$ ratio for the DE1 and DC1 tests (partially jacked at $100 \mathrm{~g}$ ) is equal to $0 \cdot 19$ and to $0 \cdot 42$ for the piles jacked at $1 \mathrm{~g}$. In Blanc and Nivoche (2014), the tension-to-compression capacity ratios for jacked and bored piles are 0.2 and 0.65 , respectively. Therefore, piles (partially) jacked at $100 \mathrm{~g}$ behave like jacked piles whereas piles jacked at $1 \boldsymbol{g}$ behave halfway between bored and jacked piles.

To explain these experimental results and the local mechanisms taking place, the load is decomposed into shaft and tip resistances. The data from the load sensor near the pile tip (4.6 m above for the prototype) and at the pile head have been recorded. However, the load values from the sensor near the pile bottom do not represent the tip resistance $V_{\mathrm{b}}$; the lateral friction on the tip of the pile should be avoided to obtain the overall tip $V_{\mathrm{b}}$ and shaft $V_{\mathrm{s}}$ capacities. To remove the friction around the tip, the interface friction angle is required. The CPT-based method ICP-05 is adopted here for this purpose. 


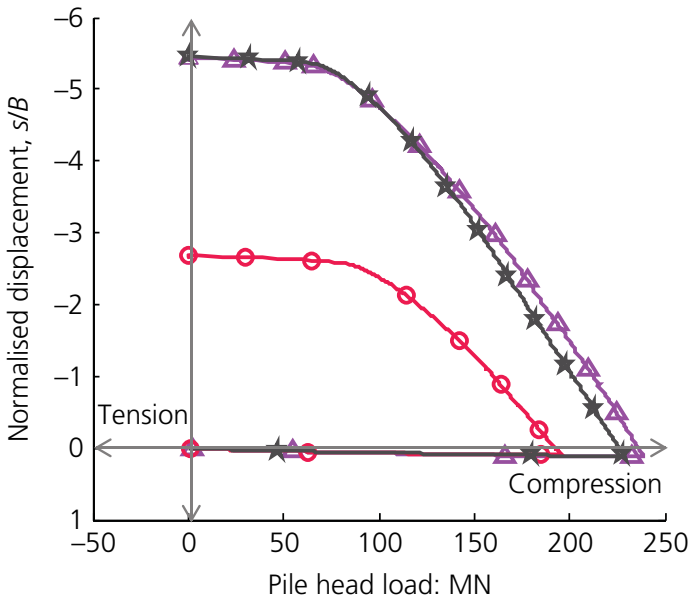

(a)

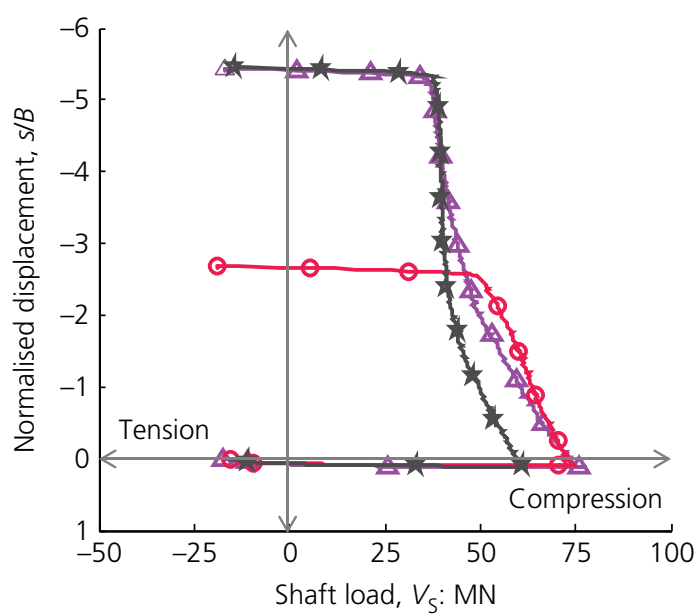

(c)

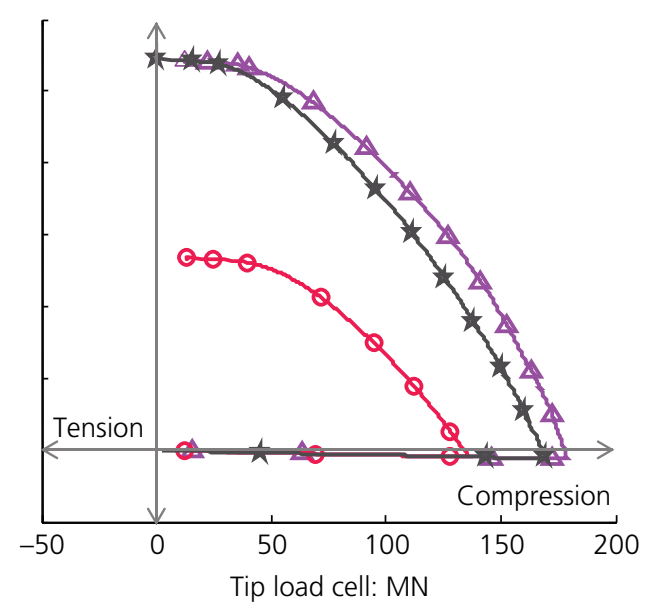

(b)

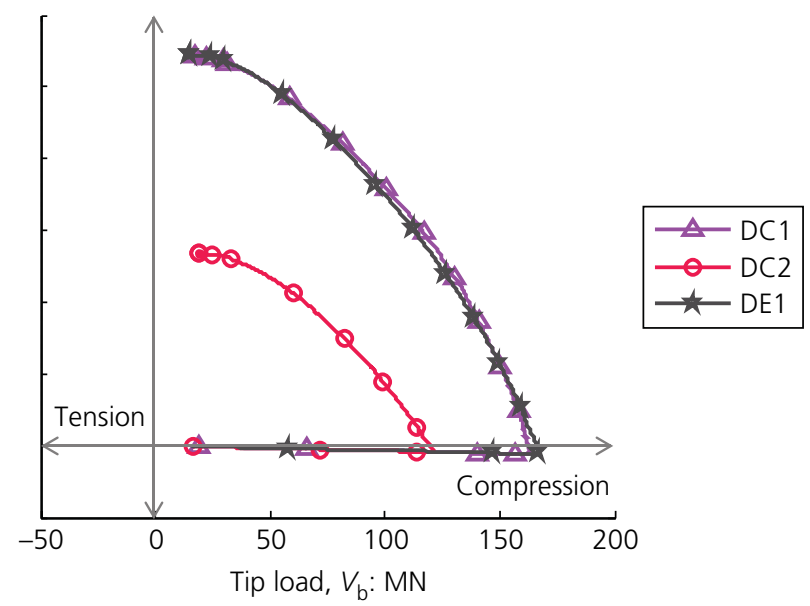

(d)

Figure 5. Jacking phase for monotonic loading tests (prototype scale): (a) load head sensor, (b) tip load cell, (c) shaft resistance against normalised displacement and (d) tip load against normalised displacement

\subsubsection{Tip and shaft capacities}

The tip $V_{\mathrm{b}}$ and shaft $V_{\mathrm{s}}$ capacities are presented, for each pile and for monotonic loading tests, in Figures 5 and 6(c) and 6(d). Due to the pile and soil relative displacements, the initial values of the tip and shaft resistances are not negligible (tip resistance is positive whereas shaft resistance is negative).

For the tension tests, the tip resistance decreases rapidly down to a minimum value, corresponding to a normalised displacement between -3 and $-5 \%$ : a value slightly positive for ME1 and slightly negative for DE1. Once the minimum resistance is reached, tip resistance disappears and the initial positive and negative frictions are equal (in other words, frictions hold the pile). The shaft capacity is $-47 \mathrm{MN}$ for ME1 and $-38 \mathrm{MN}$ for DE1. These values are lower than the results obtained with compression tests, probably due to the reduction of the radial stress due to pile slenderness.

Piles of MC1 and MC2 tests behave like bored piles. With the increase in axial load, the soil around the tip first becomes denser and the shaft resistance increases while tip resistance remains (almost) constant at $\sim 80 \mathrm{MN}$. Then, the tip resistance is mobilised. In other words, at the beginning of the loading phase, the friction between the soil and the pile is fully mobilised whereas in the final stages, the increase in bearing capacity is due to the tip resistance due to compaction phenomena. 


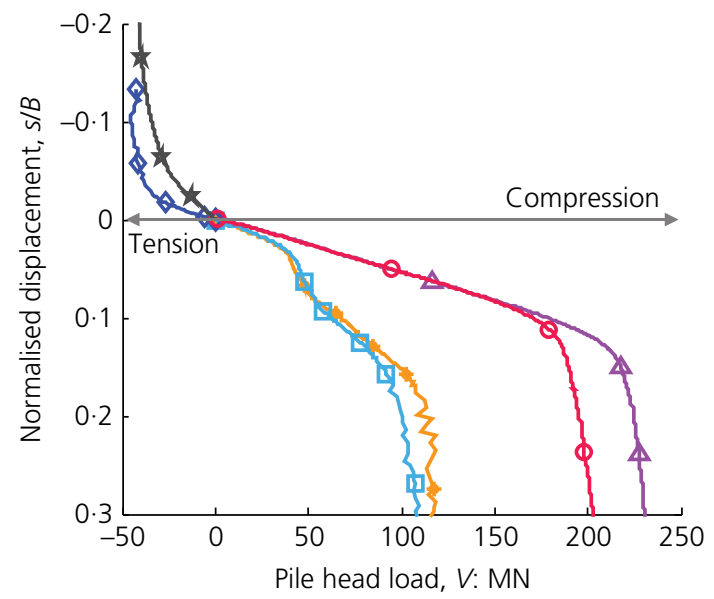

(a)

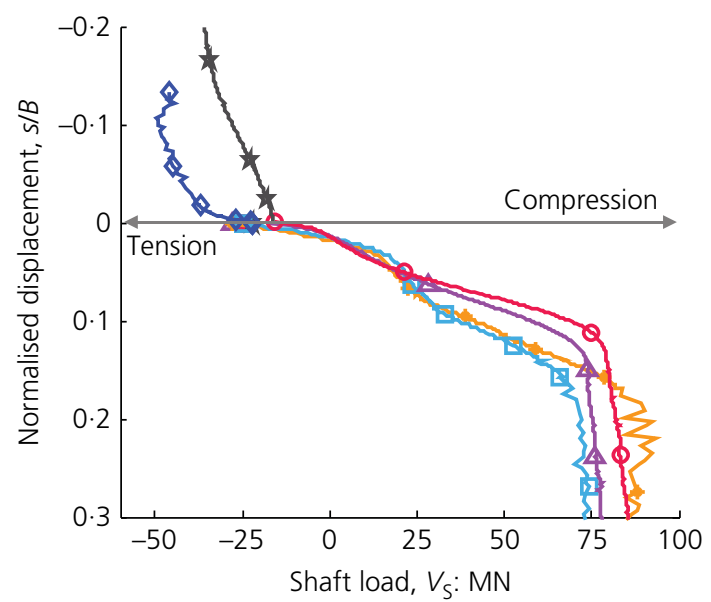

(c)

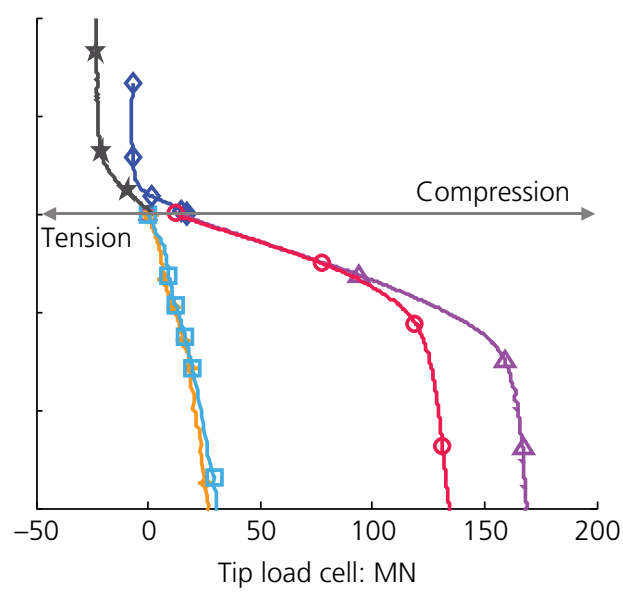

(b)

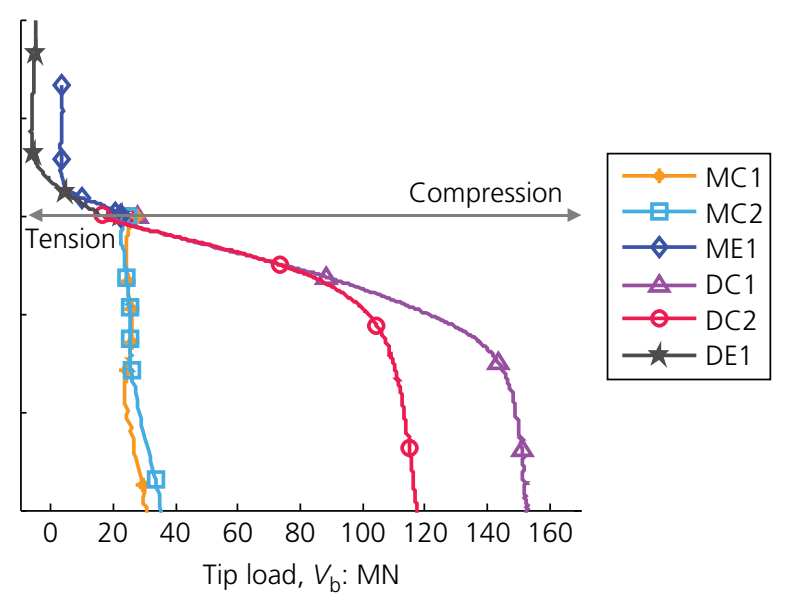

(d)

Figure 6. Monotonic loading tests (prototype scale): (a) load head sensor, (b) tip load cell, (c) shaft resistance against normalised displacement and (d) tip load against normalised displacement

In DC1 and DC2 tests, $V_{\mathrm{b}}$ and $V_{\mathrm{s}}$ first increase and then, around $14 \%$ of the normalised displacement, become (almost) constant. Due to the specific set-up conditions, the soil becomes significantly denser around the pile and the shaft and tip resistances are mobilised. The shaft resistance is $\sim 80 \mathrm{MN}$ and the tip resistances are about $150 \mathrm{MN}$ (DC1 test) and $115 \mathrm{MN}$ (DC2 test), a difference, which may be explained by the jacked length difference at $100 \mathrm{~g}$.

\subsubsection{Interface friction angle}

To determine the interface friction angle $\delta$, the CPT ICP-05 method is applied (Jardine et al., 2005; Schneider et al., 2008).
The effective radial stress $\sigma_{\mathrm{rf}}^{\prime}$ can be calculated using the CPT penetration resistance $q_{\mathrm{c}}$

$$
\begin{aligned}
& Q_{\mathrm{s}}=\pi B \int \sigma_{\mathrm{rf}}^{\prime} \tan \delta \mathrm{d} z \\
& \sigma_{\mathrm{rf}}^{\prime}=\left[a \frac{q_{\mathrm{c}}}{34}\left(\frac{h^{\prime}}{(B / 2)}\right)^{-0 \cdot 38}\left(\frac{\sigma_{\mathrm{v} 0}^{\prime}}{P_{\mathrm{a}}}\right)^{0 \cdot 13}\right]+2 G_{\mathrm{s}} \frac{\Delta r}{(B / 2)}
\end{aligned}
$$

where $Q_{\mathrm{s}}$ is the pile shaft capacity; $B$ is the pile diameter in m; $\sigma_{\mathrm{rf}}^{\prime}$ is the radial stress in $\mathrm{MPa} ; \delta$ is the interface angle of friction; $\sigma_{\mathrm{v} 0}^{\prime}$ is the free-field vertical stress in MPa; $P_{\mathrm{a}}$ is the atmospheric pressure in $\mathrm{MPa} ; h^{\prime}$ is the distance from the tip in $\mathrm{m}$; 
$q_{\mathrm{c}}$ is the CPT penetration resistance in MPa; $a$ is a coefficient equal to 1 for tension and 0.8 for compression; $G_{\mathrm{s}}$ is the shear stress modulus of soil in $\mathrm{MPa} ; \Delta r$ is the mean radius of soil particles.

To calculate the interface friction angle $\delta$, the foundation is considered as a short pile of $446 \mathrm{~mm}$ (the axial sensor in the pile and tip length are not taken into account) so, the load at the tip of the shorter pile is given by the axial load sensor near the tip of the pile. The difference between the head load and the load measured by the sensor near the tip gives the shaft capacity $Q_{\mathrm{s}}$ of the upper part of the embedded pile (shorter pile). The CPT penetration resistance $q_{\mathrm{c}}$ was measured during the experimental campaign that has been previously carried out (Blanc et al., 2015) and compared with the CPT results proposed by Bolton et al. (1999) from different centrifuge facilities: $q_{\mathrm{c}}=2 \cdot 7 z$ in $\mathrm{MPa}$ (where the depth, $z$, is in $\mathrm{m}$ ).

In view of the previous equation, the interface friction angle $\delta$ can be calculated. Values are given in Figures 7(a) and 7(b). For the tension ME1 test, $\delta$ is equal to $19.9^{\circ}$ and for the compression $\mathrm{MC} 1$ and $\mathrm{MC} 2$ tests, $\delta$ at failure is $28.8^{\circ}$ and $23.5^{\circ}$, respectively. For piles jacked at $100 \mathrm{~g}$ (DE1, DC1 and DC2 tests), $\delta$ is $16 \cdot 2^{\circ}, 24 \cdot 8^{\circ}$ and $26 \cdot 8^{\circ}$, respectively. This difference in the interface friction angle $\delta$ is probably the reason why DE1 and DC1 tests provide varying results during the jacking phase.

The results obtained for piles under compression are in good agreement with practice. The results of the tension tests, on the other hand, appear too low. This could be attributed to the correcting factor of 0.8 involved in the ICP method for the calculation of the decrease in radial stresses in order to take the slenderness of the piles into account. Using the previous values of the interface friction angle on the entire embedded pile, the head load is decomposed into tip and shaft capacities.

\subsection{Single piles under cyclic loading}

\subsubsection{Influence of axial cyclic loading}

Piles jacked at $1 \boldsymbol{g}$ are studied through force-controlled tests. Four parameters are necessary to describe the cyclic sequence: (a) the mean load $V_{\mathrm{a}},(b)$ the half load amplitude $V_{\mathrm{cy}},(c)$ the load frequency and $(d)$ the number of cycles $N$.

First, the load is increased to $V_{\mathrm{a}}$. Then, the sine signal is applied at a frequency of $0 \cdot 1 \mathrm{~Hz}$. The cyclic load components are expressed as the ratio of the ultimate bearing capacity deduced from monotonic loading tests.

Cyclic loading is split into two categories: one-way $\left(V_{\text {cy }} \leq V_{\mathrm{a}}\right)$ or two-way tests $\left(V_{\mathrm{cy}}>V_{\mathrm{a}}\right)$. Table 6 presents the results for all the cyclic tests.

Figure 8 presents typical results for a one-way cyclic test (the COW2 test conducted in pure tension). Figure 8(b) shows that the normalised irreversible displacement increases with the number of cycles. Suddenly, and after only a few cycles, the pile is ejected whereas the load remains above the axial tension capacity $\left(V_{\mathrm{u}, \mathrm{t}}=-43 \mathrm{MN}\right)$. This behaviour corresponds to the cyclic failure of the pile: the medium displacement rate stays

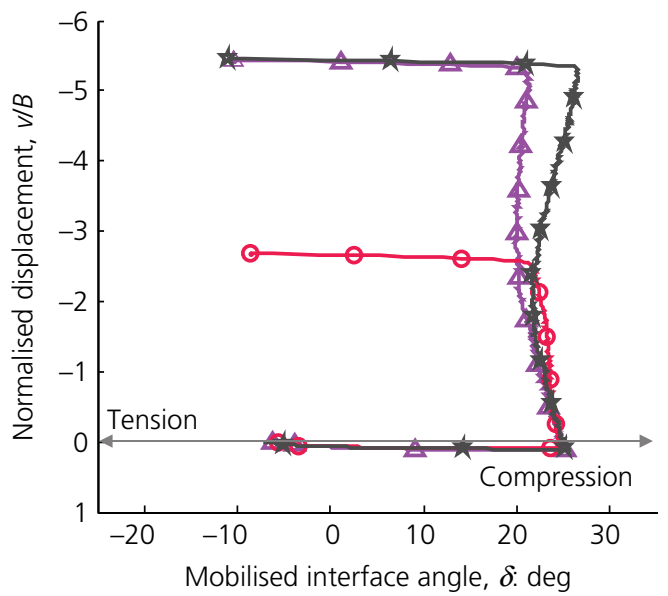

(a)

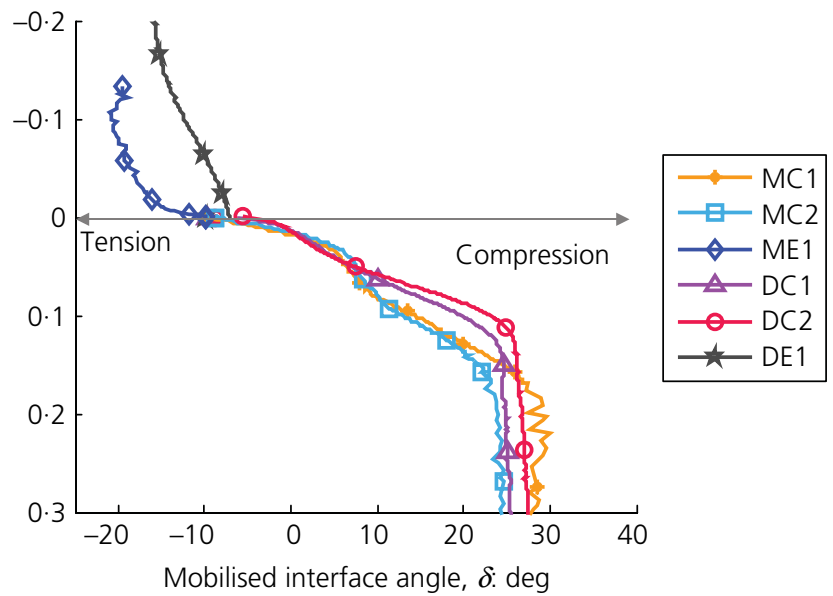

(b)

Figure 7. Monotonic loading test mobilised interface angle of friction (prototype scale): (a) jacking phase and (b) loading test 
$S / B$

\begin{tabular}{|c|c|c|c|c|c|c|c|}
\hline Test & $V_{a} / V_{u, t}$ & $V_{\mathrm{a}} / V_{\mathrm{u}, \mathrm{c}}$ & $V_{\text {cy }} / V_{a}$ & $N$ & $($ for $N=1500)$ & $N_{f}$ & $\left(s_{\mathrm{u}, \mathrm{c}}\right.$ or $\left.s_{\mathrm{u}, \mathrm{t}}\right) / B$ \\
\hline cow1 & 0.28 & - & -1 & 1500 & $-0 \cdot 14$ & - & \\
\hline cow2 & 0.42 & - & -1 & - & - & 230 & -0.35 \\
\hline cow3 & 0.46 & - & -1 & - & - & 133 & -0.35 \\
\hline CTW1 & - & 0.02 & 1.8 & 1500 & -0.02 & - & - \\
\hline CTW2 & - & $0 \cdot 11$ & $1 \cdot 8$ & 1500 & -0.78 & - & - \\
\hline CTW3 & - & 0.18 & $1 \cdot 8$ & - & - & 33 & -0.7 \\
\hline
\end{tabular}

Table 6. Cyclic loading test results (prototype scale)

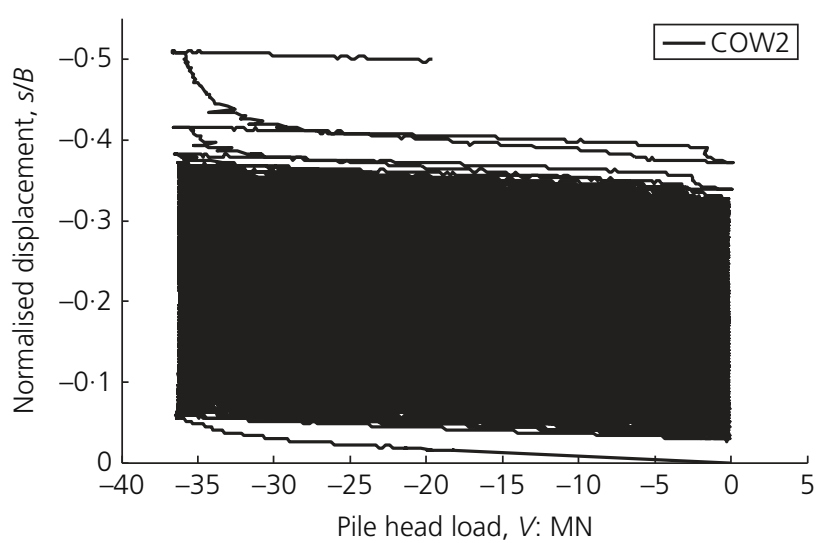

(a)

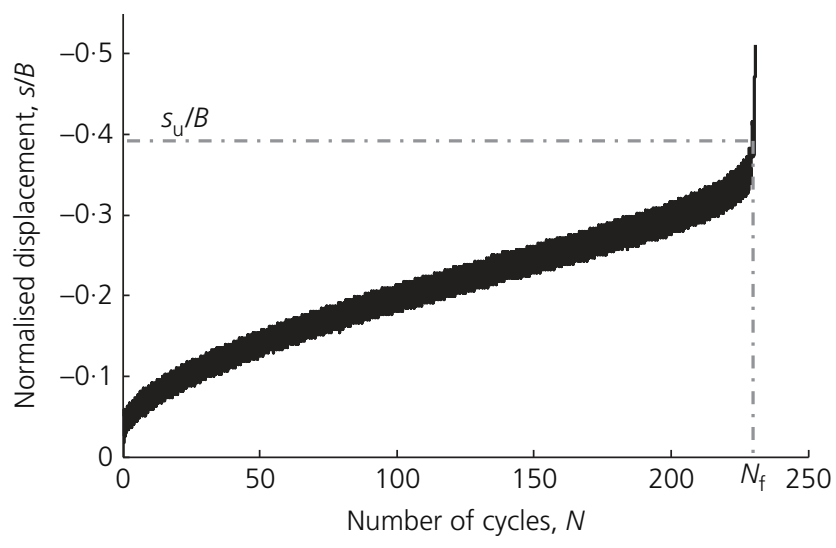

(b)

Figure 8. COW2 cyclic test in pure tension (prototype scale):

(a) head load against normalised displacement and (b) normalised displacement against number of cycles

constant first, then suddenly increases. The slope breaking point defines failure. Failure occurs after 230 cycles and for a normalised displacement of about $-35 \%$ (COW2). Cyclic failure is probably due to uniform degradation of the friction coefficient between the soil and the pile due to some change in grain properties (roughness decrease) and in the effective radial stress.

Pile cyclic failure is characterised by two parameters: $(a)$ the number of cycles at failure $N_{\mathrm{f}}$ and $(b)$ the ultimate normalised displacement $\left(s_{\mathrm{u}, \mathrm{c}}\right.$ or $\left.s_{\mathrm{u}, \mathrm{t}}\right) / B$ at failure. In what follows, the authors use the first criterion. Several tests, however, have reached 1500 cycles without failure.

\subsubsection{Stability diagram}

The stability diagram proposed by Poulos (1988) is here adapted to analyse the tests (Figure 9). Three regions are identified: (a) a stable region (for small cyclic components), where cyclic loading does not affect the pile capacity (more than 1500 cycles without failure); (b) a metastable region, where cyclic loading causes a limited reduction in load capacity; and (c) an unstable region, where cyclic loading results in pile failure within a small number of cycles ( $<100$ cycles). The number of applied cycles and the normalised displacement at the end of each test are indicated in brackets. The possible load values are identified with a triangular shape with a horizontal axis base between $V_{\mathrm{a}} / V_{\mathrm{u}, \mathrm{c}}=1$ and $V_{\mathrm{a}} / V_{\mathrm{u}, \mathrm{c}}=-0.42$ $\left(V_{\mathrm{a}}=V_{\mathrm{u}, \mathrm{t}}\right)$. This horizontal line corresponds to the monotonic tests. From these two points, the right side of the triangle crosses the vertical axis at $V_{\mathrm{cy}} / V_{\mathrm{u}, \mathrm{c}}=1$ and the left side at $V_{\mathrm{cy}} / V_{\mathrm{u}, \mathrm{c}}=0.42\left(V_{\mathrm{cy}}=V_{\mathrm{u}, \mathrm{t}}\right)$. The closer the loading is to the triangular envelope, the higher the instability is. As regards the tests, the ultimate normalised displacement is greater than for the monotonic tests. Furthermore, except for the stable case, $s_{\mathrm{u}, \mathrm{t}}$ is higher than the conventional $B / 10$ value.

The two-way CTW1 test is representative of a realistic offshore axial loading case. The loads applied in CTW2 and CTW3 are five and eight times higher than the load in CTW1, respectively. They are displayed in Figure 7 as a line starting from the origin with a slope of $V_{\text {cy }} / V_{\mathrm{a}}=1 \cdot 8$. All the load cases on this 


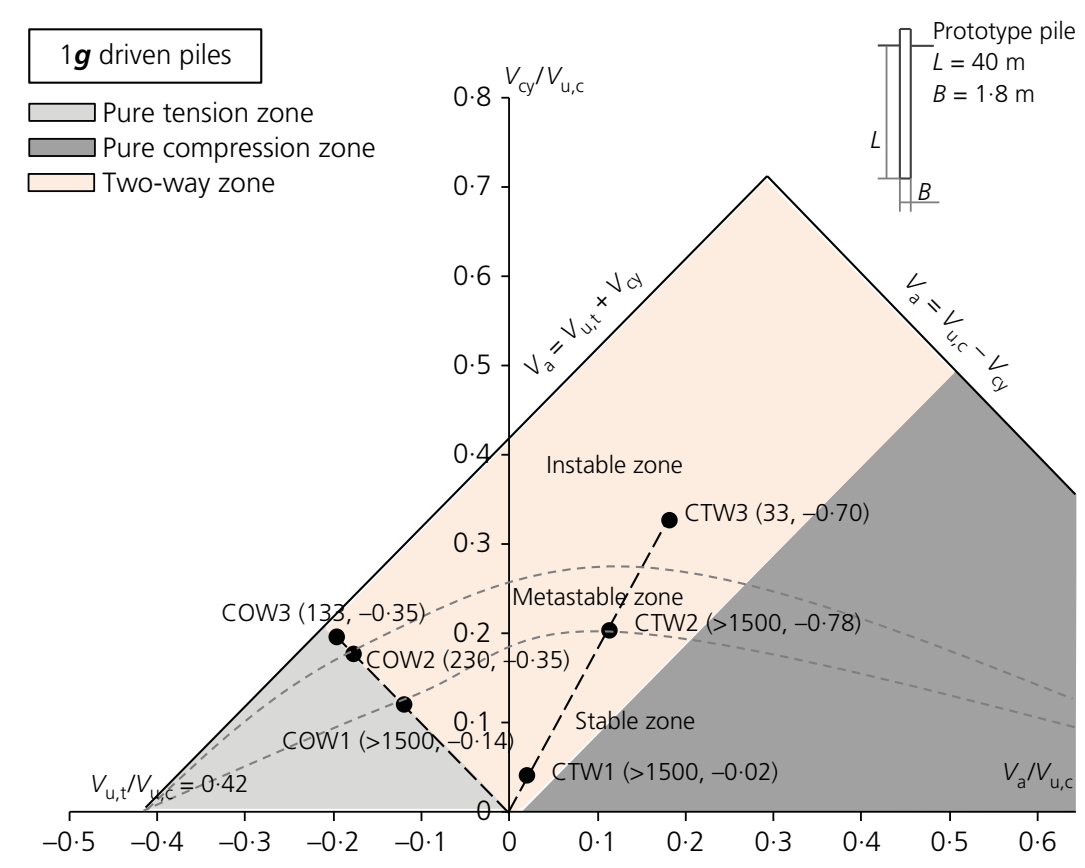

Figure 9. Stability diagram of $\mathbf{1 g}$ jacked piles tested at $100 \boldsymbol{g}$

line from the origin to CTW2 are situated in the stable zone. In CTW3 test, failure is reached under tension for a number of cycles equal to 33 . Here, the pile is characterised as unstable with a corresponding ultimate normalised displacement of $-0 \cdot 70$.

\subsection{Jacket structure under lateral loading}

The platform of the jacket structure transfers to the piles the lateral loads applied at the top of the jacket foundation mainly as axial loads and bending moments. The stability diagram of single piles can therefore be used as a first step to predict the stable zone for a jacket foundation. The design of independent single piles is often conservative since it cannot take into account the largest stiffness of the connected piles.

Table 7 presents the average, cyclic amplitude, maximum and minimum loads at the head of each jacket pile for JC00 and JC45 tests (the dead load and the horizontal load are taken into account). The number of cycles and the normalised displacement at the end of each test are also shown.

Figure 10 works like a zoom on details of the stable zone of the stability diagram (from Section 4.2.2), where the

\begin{tabular}{|c|c|c|c|c|c|c|c|c|c|}
\hline Test & Pile & Pile, $V_{a}$ : MN & Pile, $V_{\text {cy: }}$ MN & Pile, $V_{\text {max }}: M N$ & Pile, $V_{\text {min }}: M N$ & Pile, $V_{a} / V_{u, c}$ & Pile, $V_{\mathrm{cy}} / V_{\mathrm{u}, \mathrm{c}}$ & $N$ & $s / B$ \\
\hline \multirow[t]{2}{*}{$\mathrm{JCOO}$} & $\mathrm{P} 1=\mathrm{P} 2$ & $1 \cdot 7$ & $3 \cdot 6$ & $5 \cdot 3$ & -1.9 & 0.017 & 0.035 & 1500 & 0.0014 \\
\hline & $P 3=P 4$ & 8.7 & $3 \cdot 6$ & $12 \cdot 3$ & $5 \cdot 1$ & 0.086 & 0.035 & 1500 & 0.0024 \\
\hline \multirow[t]{3}{*}{$J C 45(a)$} & P1 & $2 \cdot 7$ & $5 \cdot 1$ & $7 \cdot 8$ & $-2 \cdot 4$ & 0.027 & 0.05 & 1500 & 0.0038 \\
\hline & $P 2=P 4$ & $2 \cdot 1$ & $0 \cdot 8$ & $2 \cdot 9$ & $1 \cdot 3$ & 0.021 & 0.008 & 1500 & 0.0095 \\
\hline & P3 & $12 \cdot 9$ & $5 \cdot 1$ & 18 & $7 \cdot 8$ & 0.127 & 0.05 & 1500 & 0.018 \\
\hline \multirow[t]{3}{*}{$J C 45(b)$} & P1 & $-2 \cdot 4$ & $10 \cdot 2$ & $7 \cdot 8$ & $-12 \cdot 6$ & -0.023 & $0 \cdot 1$ & 5000 & -0.0259 \\
\hline & $P 2=P 4$ & $2 \cdot 7$ & 0.2 & $2 \cdot 9$ & $2 \cdot 6$ & 0.027 & 0.002 & 5000 & 0.0089 \\
\hline & P3 & 18 & $10 \cdot 2$ & $28 \cdot 2$ & $7 \cdot 8$ & 0.178 & 0.1 & 5000 & 0.0321 \\
\hline
\end{tabular}

Table 7. Jacket pile test results for each pile (prototype scale) 


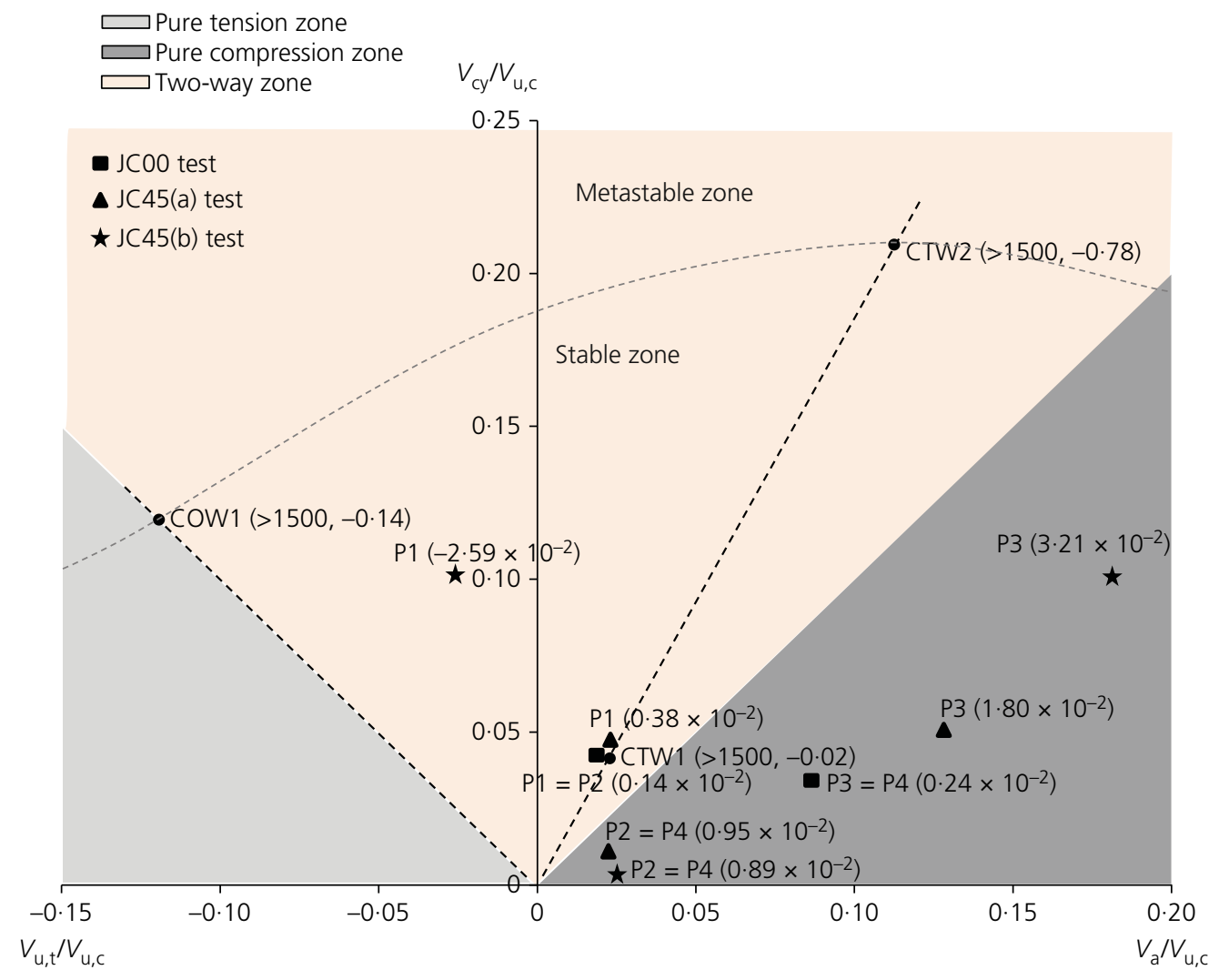

Figure 10. Stable zone of the stability diagram for single and jacket piles (prototype scale)

results obtained for the jacket piles are reported. The figure gives the normalised displacements at the end of each test only.

JC00 test reproduces the tension load of CTW1. During the JC00 test, the normalised displacement is equal to $0 \cdot 14 \%$ for piles in tension and to $0 \cdot 24 \%$ for piles in compression (the displacement due to the dead load is greater than the displacement due to the tension component). The displacements obtained for the jacket piles are much smaller than the displacements of a single pile. Piles in the jacket structure configuration are more stable than single isolated piles.

JC45 test is divided into two parts: JC45(a) and JC45(b) with 1500 and 5000 cycles, respectively. In JC45(a), the cyclic horizontal load corresponds to the load applied in JC00. The load applied in $\mathrm{JC45(b)}$ test is twice the horizontal load applied in JC45(a). The normalised displacement is $-2 \cdot 59 \%$ for P1 and $3 \cdot 21 \%$ for P3 for the JC45 test. The loads applied to the jacket piles are very low compared with the loads applied to single piles.
In the stability diagram (Figure 10), all the jacket foundation piles (P1, P2, P3, P4) are in the stable zone. The maximum and minimum loads are lower than those applied on single piles (CTW2 and COW1 (stable zone limit)). Thus, it may be concluded that the stability diagram of the single piles can be used to predict the stable zone for jacket piles. The design of independent single piles is a conservative approach because it cannot take into account the higher stiffness of connected piles and the possible compensations in terms of carrying loads.

\section{Conclusions}

The experimental campaign conducted to examine the axial behaviour of jacket piles for offshore wind turbines is presented in this paper. More specifically, the axial behaviour of single piles (prototype dimensions: $1.8 \mathrm{~m}$ in diameter and an embedded length of $40 \mathrm{~m}$ ) and of an offshore wind turbine jacket structure foundation is studied using a geotechnical centrifuge at $100 \mathrm{~g}$. The single model piles are jacked at $1 \mathrm{~g}$ and $100 \mathrm{~g}$ and the jacket foundation at $1 \mathrm{~g}$. The model soil is made 
of dense Fontainebleau sand. The purpose of this study is to investigate the significant difference between the single pile performance and that of the comparable pile in a jacket foundation. The influence of the installation conditions (jacked at $1 \mathrm{~g}$ and $100 \mathrm{~g}$ ) is also discussed.

The axial capacity of the piles is determined from monotonic tension and compression tests and the results from the tests carried out on the single piles jacked at $1 \mathrm{~g}$ and $100 \mathrm{~g}$ are compared: $(a)$ the tension tests show that the set-up conditions do not significantly influence pile tension capacity but affect the displacement necessary to develop the shaft capacity; piles jacked at $100 \mathrm{~g}$ require $61 \%$ more displacement than piles jacked at $1 \boldsymbol{g} ;(b)$ the compression tests reveal that the set-up conditions significantly influence the compression capacity $V_{\mathrm{u}, \mathrm{c}}$, which increases by more than $80 \%$ for piles jacked at $100 \mathrm{~g}$. The ultimate normalised displacement $s_{\mathrm{u}} / B$ is (only) $26 \%$ higher than for piles jacked at $1 \mathrm{~g}$.

The interface friction angle is calculated using the ICP-05 method. The axial capacity is decomposed into shaft and tip resistances. For the compression tests carried out on single piles jacked at $1 \boldsymbol{g}$, the shaft resistance first increases whereas the tip resistance remains (almost) constant. Then, when the friction around the pile is fully mobilised, the tip resistance alone increases due to some soil compaction phenomena under the tip. For the compression tests carried out on single piles jacked at $100 \mathrm{~g}$, both shaft and tip resistances increase from the start of the test, which probably reflects the influence of the set-up method.

Some cyclic tests on single piles jacked at $1 g$ have also been conducted. The results are plotted in the stability diagram proposed by Poulos (1988) and the different stability regions have been identified.

A jacket foundation composed of four piles has also been tested in the geotechnical centrifuge. The pile performances are compared with the results obtained with single pile tests. All the test results are in the stable zone, which demonstrate that the stability of the jacket foundation under cyclic loading can be studied as single pile tests. The maximal normalised settlements obtained for the jacket piles are $3 \cdot 21 \%$; a value $3 \cdot 1$ times lower than the $B / 10$ failure criteria and more than ten times lower than failure values obtained for single piles under cyclic loading. This difference in the behaviour is due to the platform linking the piles of the jacket foundation, which behaves as a monolithic solid body presenting an increased stiffness and smaller settlements. The platform transfers the lateral loads applied at the top of the jacket foundation to the piles mainly as axial loads and bending moments. The stability diagram of single piles can therefore be used as a first step to predict the stable zone for a jacket foundation. The design of independent single piles is often conservative since it cannot take into account the largest stiffness of connected piles.

More research work needs to be carried out using the centrifuge to examine jacket foundation behaviour under higher cyclic loading in order to investigate the ability to predict failure from single pile results and to validate advanced soilstructure interaction numerical models.

\section{Acknowledgements}

The authors acknowledge the Region Pays de la Loire for its financial support within the context of the CHARGEOL ('Fondations sous chargements complexes') research programme. The authors also acknowledge all the members of the technical team of the IFSTTAR's geotechnical centrifuge. Special thanks to the Association Nationale Recherche Technologie (ANRT) and INNOSEA for providing the funding for this doctoral thesis (CIFRE-Conventions Industrielles de Formation par la REcherche).

\section{REFERENCES}

ACL (Atkins Consultants Ltd) (2000) Cyclic Degradation of Offshore Piles. Health and Safety Executive, London, UK, HSE Offshore Technology Report OTO 2000013.

Afnor (2012) NF P 94-262: Justification of geotechnical work national application standards for the implementation of Eurocode 7 deep foundations. Afnor, Paris, France.

Andersen K, Puech A and Jardine R (2013) Cyclic resistant geotechnical design and parameter selection for offshore engineering and other application. In Proceeding of TC 209 Workshop - 18th ICSMGE, Paris, France (Puech A (ed.)). Presses des Ponts, Paris, France, pp. 9-44.

API (American Petroleum Institute) (2011) API RP 2GEO: Geotechnical and foundation design considerations. American Petroleum Institute, Washington, DC, USA.

Benzaria O, Puech A and Le Kouby A (2013) Cyclic axial tests for jacked piles in dense sand. In Proceeding of TC 209 Workshop - 18th ICSMGE, Paris, France (Puech A (ed.)). Presses des Ponts, Paris, France, pp. 2323-2326.

Blanc M and Nivoche M (2014) Centrifuge Tests on Jacked Pile: a) Study of the Set-Up Method b) Study of the Effect of the Load History, Preliminary Tests. IFSTTAR, Nantes, France.

Blanc M, Thorel L, Isorna R et al. (2015) Centrifuge investigation of the axial cyclic behaviour of a single pile used for the foundation of a jacket type offshore wind turbine. In Proceedings of the 3rd International Symposium on Frontiers in Offshore Geotechnics, Oslo, Norway. CRC Press/Balkema, Leiden, the Netherlands, pp. 521-526. 
Bolton MD, Gui MW, Garnier J et al. (1999) Centrifuge cone penetration tests in sand. Géotechnique 49(4): 543-552, http://dx.doi.org/10.1680/geot.1999.49.4.543.

Chan S and Hanna TH (1980) Repeated loading on single piles in sand. Journal of the Geotechnical Engineering Division ASCE 106(2): 171-188.

Chow FC (1997) Investigations into Displacement Pile Behaviour for Offshore Foundations. PhD thesis, University of London (Imperial College), London, UK.

Clausen CJF, Aas PM and Karlsrud K (2005) Bearing capacity of driven piles in sand, the NGI approach. In Proceedings of the International Symposium on Frontiers in Offshore Geotechnics, Perth, Australia (Gourvenec S and Cassidy M (eds)), pp. 677-681.

Cuellar P (2010) Pile Foundations for Offshore Wind Turbines: Numerical and Experimental Investigations on the Behaviour under Short-Term and Long-Term Cyclic Loading. PhD thesis, University of Berlin, Berlin, Germany.

DNV (Det Norske Veritas) (1977) DNV: rules for the design construction and inspection of off-shore structure, Appendix F, foundations. Det Norske Veritas, Oslo, Norway.

DNV (2012) OS-J101: Design of offshore wind turbine structures. Det Norske Veritas, Oslo, Norway.

Finnie IMS and Randolph MF (1994) Punch-through and liquefaction induced failure of shallow foundations on calcareous sediments. Behaviour of Offshore Structure, BOSS'94, Boston, MA, USA, Pergamon Press, MA, USA, pp. 17-26.

Garnier J, Kus B and Levacher D (1993) Cartographier des densités de massifs de sable reconstitués par pluviation. In Proceedings of the 6ème colloque Franco-Polonais de mécanique des sols, Douai, France. Ecole des Mines de Douai, pp. 105-122 (in French).

Guefrech A, Rault G, Chenaf N et al. (2012) Stability of cast in place piles in sand under axial cyclic loading. In Proceedings of the 7th International Conference on Off-shore Site Investigation and Geotechnics: Integrated Technologies - Present and Future, London, UK. Society for Underwater Technology, London, UK, pp. 329-334.

INNOSEA (2014) Calculation of Loads for Jacket Piles Foundation (Internal Report). INNOSEA, Nantes, France (in French).

Jardine R and Standing RJ (2000) Pile Load Testing Performed for HSE Cyclic Loading Study at Dunkirk, France Two Volumes Offshore Technology Report OTO2000 007. Health and Safety Executive, London, UK.

Jardine RJ and Standing JR (2012) Field axial cyclic loading experiments on piles driven in sand. Soils and Foundations 52(4): 723-736.

Jardine R, Chow F, Overy R and Standing J (2005) ICP Design Method for Jacked Piles in Sands and Clays. Thomas Telford, London, UK.
Khemakhem M, Chenaf N, Garnier J, Favraud C and Gaudicheau P (2012) Development of degradation laws for describing the cyclic lateral response in clay. In Proceedings of the 7th International Conference on Off-shore Site Investigation and Geotechnics: Integrated Technologies - Present and Future, London, UK. Society for Underwater Technology, London, UK, pp. 271-278.

Kolk HJ, Baaijens AE and Senders M (2005) Design criteria for pipe piles in silica sands. In Proceedings of the International Symposium on Frontiers in Offshore Geotechnics, Perth, Australia (Gourvenec S and Cassidy M (eds)), pp. 711-716.

Lehane BM (1992) Experimental Investigations of Pile Behaviour Using Instrumented Field Piles. $\mathrm{PhD}$ thesis, University of London (Imperial College), London, UK.

Lehane BM, Schneider JA and Xu X (2005) The UWA-05 method for prediction of axial capacity of driven piles in sand. In Proceedings of International Symposium on Frontiers in Offshore Geotechnics, Perth, Australia (Gourvenec S and Cassidy M (eds)). pp. 683-689.

Lehane BM, O'Loughlin CD, Gaudin C and Randolph MF (2009) Rate effects on penetrometer resistance in kaolin. Géotechnique 41(1): 41-52, http://dx.doi.org/10.1680/geot. 2007.00072.

Lings ML and Dietz MS (2005) The peak strength of sand-steel interfaces and the role of dilation. Soils and Foundations 45(6): 1-14.

McNeilan T and Bugno WT (1985) Cone penetration test results in offshore. California Silts, Strength Testing of Marine Sediments: Laboratory and In-Situ Measurements (Chaney RC and Demars KR (eds)). ASTM, Philadelphia, PA, USA, pp. 55-71.

Poulos HG (1988) Cyclic stability diagram for axially loaded piles. Journal of Geotechnical Engineering 114(8): $877-895$.

Puech A (2013) Advances in axial cyclic pile design: contribution of the SOLCYP project. In Proceeding of TC 209 Workshop - 18th ICSMGE, Paris, France (Puech A (ed.)). Presses des Ponts, Paris, France, pp. 1071-1096.

Puech A and Jézéquel F (1980) The effects of long-time cyclic loadings on the behavior of a tension pile. In Proceedings of the 12th Offshore Technology Conference, Houston, TX, USA, pp. 3870-3880.

Rangeard D, Zentar R, Hicher PY and Moulin G (2002) Permeability effect on pressuremeter test results. In Proceedings of the 8th International Symposium of Numerical Modelling in Geomechanics (NUMOG VIII), Rome, Italy (Pande GN and Pietruszczak S (eds)). CRC press, pp. 619-625.

Rimoy SP, Jardine RJ, Silva M et al. (2012) Local and global behaviour of cyclically loaded instrumented model 
displacement piles in sand. In Proceedings of the 7th International Conference on Off-Shore Site Investigation and Geotechnics: Integrated Technologies - Present and Future, London, UK. Society for Underwater Technology, London, UK, pp. 279-286.

Rosquöet F, Thorel L and Garnier J (2013) Pile in sand under lateral loading: development of degradation laws for describing cyclic load effects design for cyclic loading: piles foundations. In Proceeding of TC 209 Workshop - 18th
ICSMGE, Paris, France (Puech A (ed.)). Presses des Ponts, Paris, France, pp. 89-93.

Schneider J, Xu X and Lehane BM (2008) Database assessment of CPT-based design method for axial capacity of driven piles in siliceous sands. Journal of Geotechnical and Geoenvironmental Engineering 134(9): 1227-1244.

Tsuha CHC, Foray PY, Jardine RJ et al. (2012) Behaviour of displacement piles in sand under cyclic axial loading. Soils and Foundations 52(3): 393-410. 